\title{
第11回冬季オリンピック札㹸大会における 成績と体格との関係について
}

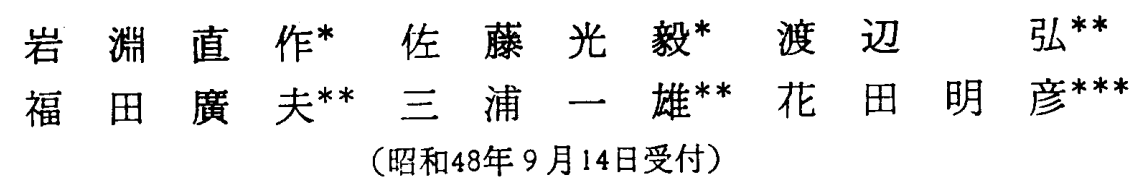

The Relationships Between the Results and Physique in the XIth Winter OIympic Games, Sapporo.

\author{
Naosaku Iwabuchi (Hirosaki University) \\ Koki Sato (Hirosaki University) \\ Hiroshi Watanabe (Research Student, Hirosaki University) \\ Hiroo Fukuda (Research Student, Hirosaki University) \\ Kazuo Miura (Research Student, Hirosaki University) \\ Akihiko Hanada (Kuroishi Senior High School, Aomori)
}

冬乎オリンピック大会の成績と体格との関係沉ついて, 相関並びと回愲係数を用いた研究は, 体育学研究その 他の文献を見ても皆無であることから，第11回冬乎オリンピック札幌大会てついて調べた桔果，次のことがわか った.

1）各競技種別と括ける参加㟟手の身長と体重との相関係数は，高いあるいはかなり高い.

2）日本選手の体格は，ほとんどの競技種目において劣っている.

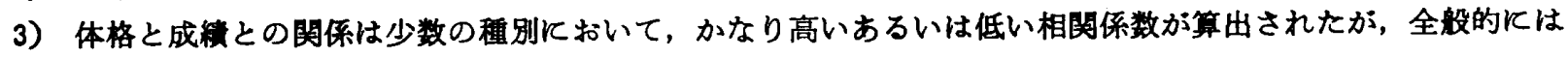
高いとはいえない。

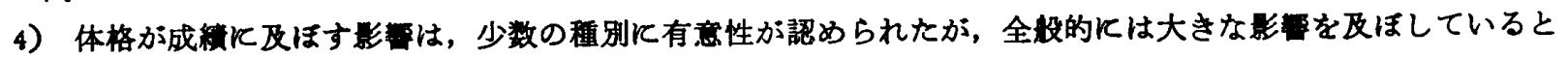
はいえない。

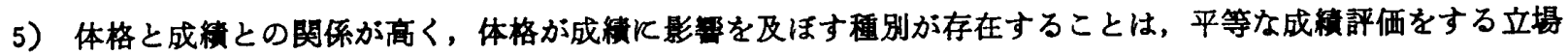
からすれば，無視できないことであると考える.

Examined the relationships between the physique of the participants and their achievement in the XIth Winter Olympic Games, Sapporo, the results were found to be as follows.

1) The computed correlation coefficients between stature and body weight of the participants were judged to be high or fairly high in each event.

2) The physique of the Japanese athletes was relatively inferior to that of the foreigners in almost all events.

3) The relationships between the results and the physique in eight items out of sixtyfour may not be ignored as significant correlation coefficients were obtained at $5 \sim 1 \%$ level. 4) Althogh, it cannot generally be said that the physique influences greatly upon the

*弘前大学教育学部, ${ }^{* *}$ 弘前大学教育学部研究生, ${ }^{* * *}$ 青森県立黒石高等学校 
results, the regression coefficients of results to physique were significant in a few items.

5) From the standpoint of the fair evaluation of the results, it would not be ignored that the relationships between the results and physique are high, and the physique influences upon the results in a few items.

(Naosaku Iwabuchi, Koki Sato, Hiroshi Watanabe, Hiroo Fukuda, Kazuo Miura, Akihiko Hanada: "The Relationships Between the Results and Physique in the XIth Winter Olympic Games, Sapporo", Research Journal of Physical Education, Vol. 18, No. 4, March, 1974, pp. 199 205)

\section{I 序一研究目的}

著者等はこれまで，第17回オリンピック・ロー マ大会並びに第18回オリンピック・東京大会に参 加した選手の身長, 体重, 成績の相関並びに回帰 係数等による分析を試みた結果 ${ }^{122) 3(4) 5) ， オ リ ン ヒ ゚ ~}$ ック大会の競技種目中，体格と成績とは高いある いはかなり高い並行関係にあり，体格の大小が成 樍にかなりの影響を及ぼしている種目が多く存在 する事実がわかった。

しかし, 冬季オリンピック大会におけるこの種 の研究について, 体育学研究その他の文献を調査 したところ，相関並びに回帰係数を用いてのもの は皆無であることから，この分野は明らかにされ ていないものと考える.

そこで, 第11回冬季オリンピック大会が 札幌で 35力国から 1100 余名の選手が参加し，6 競技35種 別にわたって開催されたのを機会に，冬季大会に おける体格と成績との関係並びに体格が成績に及 ぼす影響について分析したので，その結果を報告 する.

\section{II 方法}

対象は第11回冬季オリンピック札幌大会に参加 した選手とし，体格は一般的测定項目である身長 と体重とした。

身長と体重の資料は『第11回冬季オリンピック 札幌大会・国別参加選手名簿 ${ }^{6)}$ 』より，成績(記 録)の資料は『第11回冬季オリンピック札幌大会・ 公式記録集”』によったが, 各選手の身長, 体重, 成績がそれぞれ記載されていないものは計算から 除外した。 この中にノルデック王国といわれる北
欧のノルウェー,フィンランドの選手の身長と体 重がほとんど記载されていないので, 本研究から 除外せさるを得なかった。 また，選手の転倒等に より成績が極端に劣り，5\%水準で棄却 ${ }^{8)}$ される ものも計算から除外した。

計算処理は弘前大学計算センターの HIPAC 1039゙によった。

\section{III 研究桔果亡考察}

1 競技種別に括ける体格について

1）身長と体重との関係について

著者等が第17回のローマ大会並びに 第18回の東 京大会の陸上競技, 水泳競技, 体重別階級制種目 （ウェイトリフテング，レスリング,ボクシング， 柔道), チーム種目（バスケットボール，ハンーボ 一ル, サッカー, ホッケー, 水球), 水上脡種目 (漕艇, カヌー, ヨット) 等における身長と体重 との相関係数 ${ }^{810)}\left(\mathrm{r}_{12}\right)$ を調べたところ，ほとん どの競技種目に有意水準 5〜0.1\%の高いあるいは かなり高い相関係数が算出された。

そこで，第11回冬季オリンピック札幌大会の全 競技種別について調べると，表 1 の $\mathrm{r}_{12}$ の欄に示 す通りである。

これによると， $\mathrm{r}_{12}$ が 0.7 以上の高い相関係数が 算出されたのは 35 種別中 24 種別 $(68.6 \%)$ であ り，他の種別には 0.4 以上のかなり高い相関係数 が算出され，それらのいずれにも有意性が認めら れた。

このことは冬季大会においても，身長と体重と は高いあるいはかなり高い同時的並行関係にある ことを意味しているものであり，また，各競技種 別参加選手は極限近くまで鍜え抜かれていること 
Table 1 Correlation coefficients and regression coefficients of physique and results at all the events in the XIth Winter Olympic Games, Sapporo.

\begin{tabular}{|c|c|c|c|c|c|c|c|c|c|c|}
\hline \multirow{2}{*}{\multicolumn{2}{|c|}{ Event }} & \multirow{2}{*}{ Item } & \multirow{2}{*}{ Sex } & \multirow{2}{*}{ No. } & \multicolumn{3}{|c|}{ Correlation coefficient } & \multicolumn{3}{|c|}{ Regression coefficicient } \\
\hline & & & & & $\mathbf{r}_{12}$ & $r_{18}$ & $r_{28}$ & $\begin{array}{c}b_{12} \\
(\mathrm{~kg} / \mathrm{cm})\end{array}$ & $\begin{array}{c}b_{18} \\
(\mathrm{sec} / \mathrm{cm})\end{array}$ & $\begin{array}{c}\mathrm{b}_{28} \\
(\sec / \mathrm{kg})\end{array}$ \\
\hline \multirow{7}{*}{$\mathbf{S}$} & \multirow{3}{*}{ C } & $15 \mathrm{~km}$ & $\mathbf{M}$ & 52 & $0.743^{* * *}$ & -0.083 & 0.057 & $0.807 * *$ & -1.739 & 1.104 \\
\hline & & $30 \mathrm{~km}$ & $"$ & 49 & $0,694^{* * *}$ & 0.127 & 0.174 & $0.795^{* *}$ & 5.123 & 6.118 \\
\hline & & $50 \mathrm{~km}$ & " & 26 & $0.804^{* * *}$ & 0.099 & 0.098 & $0.750^{* *}$ & 5.409 & 5.719 \\
\hline & 1 & $40 \mathrm{kmR}$ & " & 11 & $0.810^{* * *}$ & 0.327 & 0.409 & $0.801^{* *}$ & 17.910 & 22.647 \\
\hline & \multirow{3}{*}{ C } & $5 \mathrm{~km}$ & $\mathrm{~F}$ & 35 & $0.704^{* * *}$ & -0.252 & -0.244 & $0.682^{* *}$ & -1.777 & -1.777 \\
\hline & & $10 \mathrm{~km}$ & " & 33 & $0.698^{* * *}$ & 0.031 & -0.131 & $0.694^{* *}$ & 0.509 & -2.144 \\
\hline & & $15 \mathrm{kmR}$ & " & 9 & $0.706^{*}$ & 0.284 & -0.322 & $0.595^{*}$ & 31.921 & -42.874 \\
\hline \multirow[t]{3}{*}{$\mathrm{K}$} & $\mathbf{J}$ & $70 \mathrm{~m}$ & $\mathbf{M}$ & 48 & $0.468^{* * *}$ & $-0.376^{* *}$ & -0.073 & $0.337^{* *}$ & $-0.821^{* *}$ & -0.222 \\
\hline & $\underset{\mathbf{P}}{\mathbf{M}}$ & $90 \mathrm{~m}$ & " & 44 & $0.573^{* * *}$ & -0.183 & -0.131 & $0.416^{* *}$ & -0.534 & -0.494 \\
\hline & $\mathrm{C}$ & $\mathbf{O} \quad \mathbf{M}$ & $"$ & 34 & $0.777^{* * *}$ & 0.111 & 0.038 & $0.759^{* *}$ & 0.487 & 0.170 \\
\hline \multirow[t]{6}{*}{ I } & \multirow{6}{*}{$\mathbf{P}$} & \multirow{6}{*}{$\begin{array}{l}\text { Downhill } \\
\text { Slalom } \\
\text { Giant Slalom } \\
\text { Downhill } \\
\text { Slalom } \\
\text { Giant Slalom }\end{array}$} & " & 50 & $0.649^{* * *}$ & $-0.368^{* *}$ & -0.192 & $0.749^{* *}$ & $-0.375^{* *}$ & -0.170 \\
\hline & & & " & 35 & $0.683^{* * *}$ & -0.068 & 0.122 & $1.069^{* *}$ & -0.325 & 0.373 \\
\hline & & & " & 43 & $0.710^{* * *}$ & -0.117 & 0.254 & $0.971^{* *}$ & -0.536 & 0.852 \\
\hline & & & $\mathrm{F}$ & 37 & $0.643^{* * *}$ & -0.278 & $-0.374^{*}$ & $0.584^{* *}$ & -0.110 & $-0.163^{*}$ \\
\hline & & & $" \prime$ & 18 & $0.646^{* *}$ & -0.249 & 0.425 & $0.565^{* *}$ & 0.161 & 0.314 \\
\hline & & & $" \prime$ & 31 & $0.716^{* * *}$ & -0.348 & -0.123 & $0.674^{* *}$ & -0.206 & -0.077 \\
\hline \multirow{5}{*}{$\mathrm{S}$} & \multirow{3}{*}{$\mathrm{S}$} & \multirow{3}{*}{$\begin{array}{rl}500 & \mathrm{~m} \\
1500 & \mathrm{~m} \\
5000 & \mathrm{~m}\end{array}$} & $\mathbf{M}$ & 32 & $0.830^{* * *}$ & -0.258 & $-0.434^{*}$ & $1.221^{* *}$ & -0.054 & -0.062 \\
\hline & & & $"$ & 34 & $0.740^{* * *}$ & $-0.372^{*}$ & $-0.488 * *$ & $0.894^{* *}$ & -0.231 & $-0.250^{* *}$ \\
\hline & & & $"$ & 26 & $0.736^{* * *}$ & -0.156 & -0.359 & $0.719^{* *}$ & -0.406 & -0.956 \\
\hline & \multirow{2}{*}{$\mathbf{P}$} & $10000 \mathrm{~m}$ & " & 22 & $0.686^{* * *}$ & 0.022 & -0.256 & $0.706^{* *}$ & 0.118 & -1.333 \\
\hline & & $500 \mathrm{~m}$ & $\mathbf{F}$ & 25 & $0.762^{* * *}$ & -0.024 & -0.120 & $0.764^{* *}$ & -0.005 & -0.024 \\
\hline \multirow[t]{3}{*}{$\mathrm{K}$} & \multirow{3}{*}{$\mathrm{E}$} & $1000 \mathrm{~m}$ & $" \prime$ & 30 & $0.710^{* * *}$ & -0.249 & -0.310 & $0.756^{* *}$ & -0.099 & -0.116 \\
\hline & & $1500 \mathrm{~m}$ & " & 30 & $0.721^{* * *}$ & -0.146 & -0.113 & $0.703^{* *}$ & -0.117 & -0.093 \\
\hline & & $3000 \mathrm{~m}$ & $"$ & 20 & $0.774^{* * *}$ & -0.357 & -0.409 & $0.767^{* *}$ & -0.553 & -0.640 \\
\hline \multirow{3}{*}{$\mathrm{E}$} & \multirow{3}{*}{$\begin{array}{l}\mathbf{F} \\
\mathbf{I} \\
\mathbf{P}\end{array}$} & Single & $\mathbf{M}$ & 16 & $0.722^{* *}$ & 0.021 & 0.445 & $0.493^{* *}$ & 0.410 & 12. $996^{*}$ \\
\hline & & Single & $\mathbf{F}$ & 17 & $0.800^{* * *}$ & 0.390 & $0.488^{*}$ & $0.768^{* *}$ & 9. 488 & 12. $389^{*}$ \\
\hline & & Pairs & MF & 16 & $0.747^{* * *}$ & -0.081 & 0.004 & $0.605^{* *}$ & -0.478 & 0.028 \\
\hline \multirow{2}{*}{\multicolumn{2}{|c|}{$\begin{array}{l}\text { B } \\
\text { I } \\
\text { A }\end{array}$}} & Single & $\mathbf{M}$ & 45 & $0.834^{* * *}$ & -0.065 & 0.095 & $0.861^{* *}$ & -2.936 & 4. 196 \\
\hline & & Relay & $" \prime$ & 11 & $0.844^{* *}$ & -0.143 & 0.001 & $0.771^{* *}$ & -7.062 & 0.033 \\
\hline \multirow{2}{*}{\multicolumn{2}{|c|}{$\begin{array}{l}\text { B } \\
\text { O } \\
\text { B }\end{array}$}} & 2-Man Bob & " & 18 & $0.743^{* * *}$ & -0.308 & $-0.495^{*}$ & $0.992^{* *}$ & -0.245 & $-0.295^{*}$ \\
\hline & & 4-Man Bob & $"$ & 12 & $0.626^{* *}$ & -0.217 & -0.436 & $0.748^{*}$ & -0.135 & -0.227 \\
\hline \multicolumn{2}{|c|}{ L } & Single & " & 40 & $0.777^{* * *}$ & 0.059 & -0.268 & $0.983^{* *}$ & 0.053 & -0.190 \\
\hline & & Single & $\mathrm{F}$ & 19 & $0.687^{* *}$ & -0.120 & -0.347 & $0.637^{* *}$ & -0.065 & -0.203 \\
\hline & & 2 Seater & $\mathbf{M}$ & 19 & $0.776^{* * *}$ & 0.358 & 0.146 & $0.962^{* *}$ & 0.140 & 0.046 \\
\hline & $\mathrm{H}$ & 0 & $"$ & 9 & $0.755^{* * *}$ & & & $0.873^{* *}$ & & \\
\hline
\end{tabular}

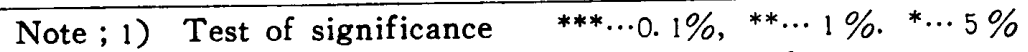

2) 1 -..Stature, $2 \cdots$ Body-weight, $3 \cdots$ Result

3) The units of regression coeffcient in JMP, COM and FIG events are scor $/ \mathrm{cm}$ and scor $/ \mathrm{kg}$

4) C-C...Cross Country, JMP...Jumping, COM...Nordic Combined, ALP...Alpen Skiing,

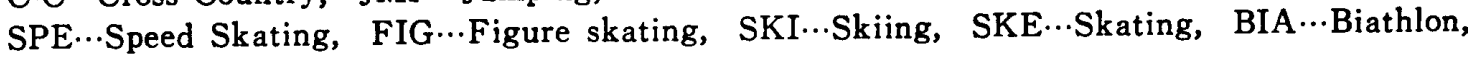
BOB...Bobsleigh, LUG...Luge, HOC...Hockey 
から，各競技種別における選手の体型類似性 ${ }^{11)}$ 高いことを示唆しているすのと考える。

2）競技種別参加選手と日本選手の体格の比較に ついて

第11回冬季オリンピック札幌大会における各競 技種別参加選手の平均身長と平均体重並びに日杢 選手の各平均値を示すと四1のよ5になる。

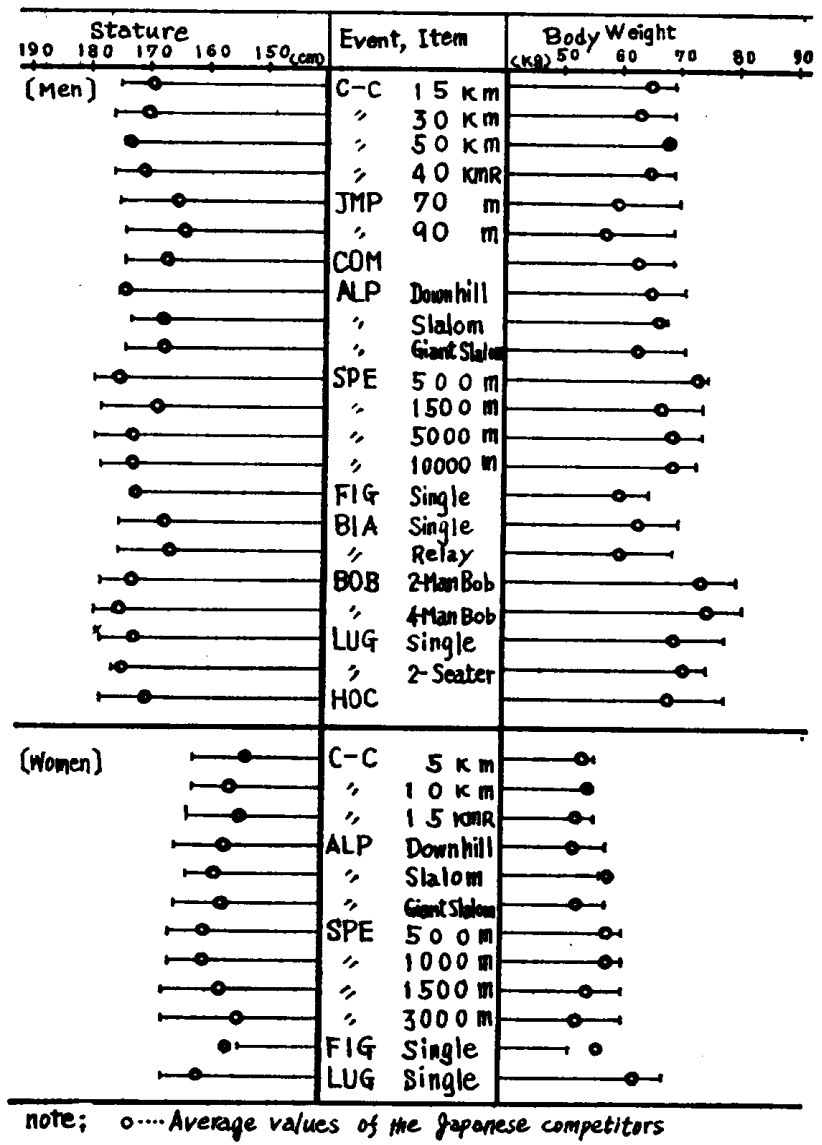

Fig. I Average stature and average bodyweight of all the participating competitors and the Japanese competitors in each event, the XIth Winter Olympic Games, Sapporo.

各競技種別の中で平均身長が大きいものは男子 の場合，スピードスケートの 500 メートル(179.19 $\mathrm{cm}), 5000$ ートル $(178.85 \mathrm{~cm})$, ボブスレー 4 人 乗り $(178.77 \mathrm{~cm})$ ，女子ではスピードスケートの 1500 メートル $(166.90 \mathrm{~cm}), 3000$ メートル (166.80 $\mathrm{cm})$, リュージュ 1 人乗り $(166.63 \mathrm{~cm})$ 等である. 小さいものは男子ではアルペンの回転 $(173.11 \mathrm{~cm})$ フィギュアのシングル $(173.25 \mathrm{~cm})$ である.

平均体重において大なるすのは，男子ではボブ
スレーの 4 人乗り $(80.96 \mathrm{~kg}), 2$ 人乗り $(80.28 \mathrm{~kg})$, 女子ではリュージュのシングル $(67.79 \mathrm{~kg})$ であり， これは次のスピードスケートの3000メートル (61. $30 \mathrm{~kg}$ )とは $1 \%$ 水準の有意差が認められる。

小なるものは, 男女ともフィギュアのシングル であり，次に小なる男子距䚙50キロメートル，女 子距離10キロメートル上はそれぞれ有意差が認め られた。

次に，各競技種別の平均身長，平均体重と日本 選手のそれぞれの平均值と比較すると，日本選手 が身長，体重ともに大なるものは女子フィギュア のシングルだけで，他に大なる種別は体重に打け る女子回転たけであった。

これらを除いて競技種目別にみると，スキ一競 技では男子の場合，身長は 0.27〜 $10.14 \mathrm{~cm}$, 体重は $0.12 \sim 11.86 \mathrm{~kg}$ ，女子の場合，身長は5.44〜8.69 cm, 体重は 0.33 5.75kg 小であり，スケート競技では 男子の場合, 身長は 1.25 9.68cm, 体重は1.75 $7.35 \mathrm{~kg}$, 女子の場合, 身長は6.40 $12.80 \mathrm{~cm}$, 体重 は $2.17 〜 8.63 \mathrm{~kg}$ 小である.バイアスロン競技では 身長は 7.85〜8.64cm，体重は $7.33 \sim 9.00 \mathrm{~kg}$ ，ボブ スレー競技では $4.27 〜 5.97 \mathrm{~cm}, 5.96 \sim 6.28 \mathrm{~kg}$ 小で ある.リュージュ競技では男子の場合，身長は $1.58 \sim 5.95 \mathrm{~cm}$, 体重は $3.54 \sim 8.20 \mathrm{~kg}$, 女子の場合, $5.63 \mathrm{~cm}, 4.79 \mathrm{~kg}$ 小であり，アイスホッケー競技で は7.70cm, $9.50 \mathrm{~kg}$ 小である.

以上のことから, 日本選手の体格はほとんどの 種目に小であり，競技においては日本選手より大 なる体格の外国選手と成績を争っていることがわ かる.

すしも，夏季大会のごとく冬季大会においても， 各競技種目成續が体格の大小によって大きくある いはかなりの影響を及ぼしているとすれば，体格 的に小なる日本選手にとっては，極めて重大な問 題10)12)13)14)15)であると考える。

\section{2 体格と成績との関係について}

身長と成績，体重と成鈢との相関係数は表 10 $r_{13}, r_{23}$ の橍に示した通りである. 多くの $r_{18}, r_{23} に$ 負の符号がついているが，これは成績の 测定単位 が時間の種別が多いからである.

これによると， $\mathbf{r}_{13}$ においては70メートル級シャ 
ンプに有意水準 1\%の低い逆相関が見られ，フル ベン男子滑降，スピードスケート男子1500メート ルに有意な低い相関が算出された。 $\mathrm{r}_{18}$ においては アルペン女子滑降，スピードスケート男子 500 メ ートル，1500メートル，フィギュフ女子シング ル, ボブスレー 2 人乗りの種別に有意水準 $5 \sim 1$ \%の低い相関並びにかなり高い相関係数が算出さ れた。

以上述べた種別について考察すると，ジャンプ 競技の場合，70メートルにおいて，日本選手はホ 一ムグランドの有利性を生かして上位入貝をした が，90メートルにおいては 6 位以内に入貴するこ とができなかった。

その理由として，90メートルは70メートルより もシャンッェのスタート地点が高くなるので，よ ク一層心理的恐怖感が伴ならこと，アプローチで のスピードが速くなるので，それだけ踏み切りの タイミングが難かしくなること，滞空時間が長く なるので，風圧などの気象条件の影響を受けやす いこと，物理的には物体の加速度は㗢く力に比例 （直線運動に打ける運動の第二法則）し，斜面上 の物体に働く前向きの力は質量と傾斜角に比例す $ろ^{(1)}$ ことから，体格の大なる選手はど スピードに 乗ってより遠くへジャンプする可能性があること など，種々の条件に起因するものと考えられる.

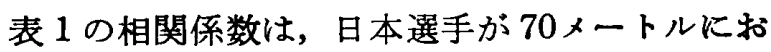
いて上位を独占し，90メートルにおいては入賞し ないために表 1 のよに算出されたことも考えら れるので，日本選手を除いた44名の相関係数を調 ベると， 70 メートルの場合， $r_{13}=-0.306$ ( $5 \%$ 水 準で有意)， $\mathrm{r}_{23}=-0.138,90$ メートルの場合， $\mathrm{r}_{18}$ $=-0.104, r_{23}=0,000$ となり, ほとんど表 1 の相 関係数と差がないことがいえる.

アルペン競技の5ちで男女滑降に有意性が認め られたが，その根拠として，滑降競技は標高差の 最も高い直線的に長く続くコースをできるだけ制 動しない上5に加速度をつけ，弾丸のごとく高速 で滑降する競技であるため，回転競技のごとく巧 みなェッジングで細かく軽快な回転技術を要する ものに比べて，体格が大きいことがスピードに有 利な影響を与えていることを示していると考え る。
スピードスケートの滑り方として，カーブでは 歩幅を小さくしてピッチをあげながら力強いキッ クでスピードをつけ，ストレートではそのスピー

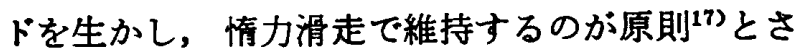
れているが，加速度をつけてょり大きな惰力を得 るためには，体格が大きいことが有利であること は自明の理である.

したがって，持久力を多く必要とする長距離よ りも，体力で短時間に勝敗を決める短距離 ( 500 , 1500 メートル）に有意な相関係数が算出されたも のと孝える.

フィギュアスケートの規定と自由を総合した成 續と身長，体重との相関係数をみると，女子シン グルの $\mathrm{r}_{28} に 5 \%$ 水準の有意性が認められた。こ れを規定, 自由別に調へててると，規定のみに有 意性が認められることがわかった。このことか ら，複雑で大きな動きの中に，芸術的印象や技術 的価值を重要視し採点する自由に比へ，動きが少 なく，しかも決められた範囲の中での正確さ，大 きさ，智の美しさ等を要求する規定に体格が大 きいことが，有利に働きかけるものと推察され る.

ボブスレーはリュージュと異なり，チームメン バーの体重に「そり」の重量を加えた最大重量の 制限があり， 2 人乗りでは競技用のヘルメット， ゴーグル，手袋などの装備をつけた状態の総重量 が $375 \mathrm{~kg}$ である．規定の最大重量に達しないとき は，鉛または鋳鉄を「そり」につけることが許さ れている.このルールによって，競技の平等化を 期しているすのと解釈される.

しかし，総重量を一定の枠内に押えたとして も，体重と成樍にかなり高い相関が算出されたこ とは，付加物よりも体重で重量制限に達する方 が，よりバランスコントロールが自由であり，ウ エイトのかけ方によるカーブの処理等において有 利であることを意味していると考える.

以上で $\mathrm{r}_{18} ， \mathrm{r}_{23}$ に有意な相関が算出された種別 についての考察を終わる.

表 1 の $\mathbf{r}_{18} ， r_{28}$ の欄においては，有意水準が認 められない種別が認められたものよりも多いが， それらの種別においては体格が成績に無関係であ るのではなく，それは，参加選手が技術的に現代 
における超一流であり，アルペン競技やスピード スケート競技等においては 100 分の1秒を競 5 の で，成績の差がはとんどないことから，統計的仡 有意性が認められることは難しいためであると推 察される。

\section{3 体格が成績に及注す影響}

第11回冬季オリンピック札幌大会の 全競技種別 における成績の体格に対する回帰係数を調べる と，表 1 の $b_{18} ， b_{28}$ の欄に示す通りである.

これによると， $b_{13}, b_{23} に 5 〜 1 \%$ 有意水準 が認められた種別は，ほとんと $\mathrm{r}_{13}, \mathrm{r}_{23}$ に有意水 準が認められた種別であることがわかる.

これらの $b_{13} ， b_{23}$ の解釈は，たと艺，男子滑 降における $\mathrm{b}_{13}$ の $-0.375(\mathrm{sec} / \mathrm{cm})$ は身長が $1 \mathrm{~cm}$ 增すごとに記録は $0.375 \mathrm{sec}$ の割合で減少し, 成積 はそれたけ良くなり，反対に身長が $10 \mathrm{~cm}$ 低い者 は $3.75 \mathrm{sec}$ 增加し，それだけ成績が悪くなること を統計的に意味していると解釈される．したがっ て，有意な回帰性が認められた競技種別の成績は 身長や体重に明らかに影響されているといえる。

試みに，スピードスケート男子 1500 メトルの 体格と成績の散布図をつくり，成績の体格に対す る回帰直線 $(\widehat{Y})$ を引くと, 図 2 のよ5になる。
四 2 の 1500 メートルにおける上位入買者の体格 は大きく，身長，体重の場合の回帰直線はどちら む右上りとなって拈り，身長や体重が大になるに つれて成績も良くなっていることがわかる.

日本選手は 2 位とも体重においては平均以下で あるにもかかわらず，回㷌直線よりも上にプロッ トされ，体格の小さい割にはよく健闍し，良い成 樍をおさめたといえる。

もしも，第20位の前田選手 $(166.0 \mathrm{~cm}, 66.0 \mathrm{~kg})$ か 優勝したオランダのアルト・シェンク迩手 (190.0 $\mathrm{cm}, 90.0 \mathrm{~kg}$ ）と同じ体格であったならば入賞して いたと推察される。

また，アイスホッケー競技に招いても，日本選 手が格䦥的なボディチェックを，作戦の中心とし て有利に進めることができるような体格であった ならば，Aグループでダームをしていたであろ 5 .

しかし，記録のみに基ついて順位を決定する平 均值評価的方法である以上, 目本選手が成績不振 とみられても仕方がないことである.

以上述ベたことから，第11回冬季オリンピック 札幌大会においては，全般的に，体格の大小が成 樍に大きな影響を及ぼしているとはいえない。し かし，少数の種目であるが，明らかに体格が成樍

$$
\begin{array}{ll}
\text { Speed Skating } 1500 \mathrm{~m} \text { (Men) } & \text { 1. Ard Schenk } \\
& \text { 2. Roar Gronvold } \\
& \text { 3. Goran Claesson } \\
& \text { O Japanese competitors }
\end{array}
$$

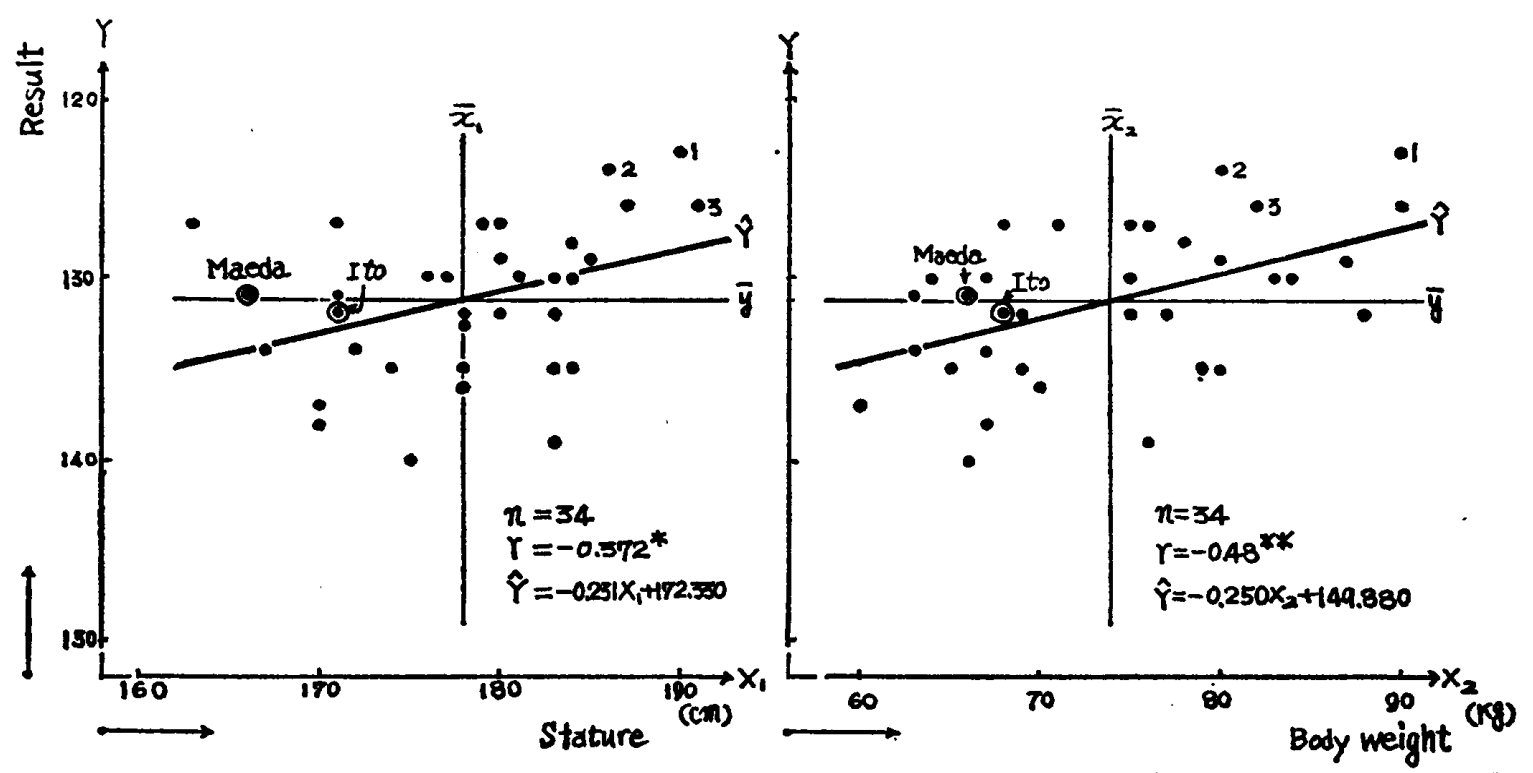

Fig. 2 Regression of results to physique in the XIth Winter Olympic Games, Sapporo. 
に影響を及ぼしている種目もあり，それらの存在 を無視できないと考える。

\section{IV 蛣論}

著者等は第11回冬季オリンピック札幌大会の成 績と体格との関係について調べた結果，次のこと がわかった。

1）各競技種別の参加選手の身長と体重とは高い あるいはかなり高い相関係数が算出された。

2）日本選手の体格はほとんどの競技種目に劣っ ている.

3）体格と成績との関係において，少数の種別に 有意水準 5 〜 1\%の汸なり高いあるいは低い相 関係数が算出されたが，全般的に体格と成績と の関係は高いとはいえない。

4）体格が成績に及ぼす影響は，少数の種別に有 意性が認められたが，全般的に体格に成績に大 きな影響を及ぼしているとはいえない。

5）体格と成績との関係が高く，体格が成績に影 響を及活している種別が存在することは，平等 な成樍評洒の立場をとるとすれば，無視できな いことであると考える。

\section{V 引用並ひに参考文献}

\section{1) 岩淵直作, A Study of Results Evaluations} Formulas at the OLYMPIC GAMES, 1969. Pp. 87.

2）岩淵直作・渡辺弘「オリンピック大会における階 級制应大関する研究」弘前大学教育学部䄫要. 23B:77-86, 1970., 24-B:20-26, 1971.

3）岩淵直作・渡辺 弘「オリンピック東京大会におけ る陸上競技成績㳊対する身長，体重の影響汇関する回 帰並びに重回帰分析」弘前大学教育学部紀要. 19-B: $1-8,1968$.

4）岩淵直作・渡辺 弘・三浦一雄「オリンピック東京 大会における陸上競技成績に対する身長, 体重の影艟
飞関する重相関分析」弘前大学教育学部紀要， 20-B: 26-38, 1969.

5）岩淵直作・佐藤光媇「オリンピック大会におけるチ 一ム種目成䋘と体格との関係江ついて」弘前大学教育 学部紀要, 24-B:14-19, 1971.

6）札㹸オリンピック冬季大会組織委員会, Participating Competitors List Classified dy Country, 1972. Pp. 67.

7）札幌オリンピック冬季大会組織委員会，Official Results, 1972. Pp. 281.

8）スネデカー，梳計的方法，第 4 版，岩波書店， 1967 Pp. 149-52.

9）弘前大学計算センター，层子尌算機HIPAC 103 の 手引老, 1960, Pp. 16 .

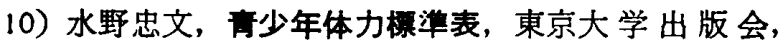
1968, Pp. 36-39

11）岩淵直作・佐藤光毅・三浦一雄「オリンピック大会 に怙ける陸上競技選手のスポーツ体型について」弘前 大学教育学部紀要, 21-B:31-39, 1969., 23-B:87-95, 1970.

12）岩淵直作「綜合体育大会における採点方式とついて の研究」体育学研究, 7:1-13, 1954., 9:590-603, 1955

弘前大学教育学部紀要, 1-1:1-36, 1965., 10:1349, 1962., 11:33-41, 1963., 12:92-107, 1964., 25B: $1-14,1971$.

13）岩淵直作「Olympic Games 等に扮ける成績評価方 式の体系化汇関する研究」弘前大学教育学部紀要, 19 -A:32-42, 1968., 20-A:1-17, 1969.

14）岩淵直作・渡辺弘「運動能力の回㷌評価 $\mathrm{T}$ ースコ 了早見表の作成」体育学研究，12-2:132-39，1968., 14-2:223-31, 1970.

15）岩洫直作 rOlympic Games 等とおける成績評価 論」弘前大学教育学部紀要, 26-B:1-13, 1971.

16）三輪光雄，物理，第24版，金羊社， 1970. Pp. 8388.

17）文部省体育局，札幅オリンピック冬季大会競技の見 方, 1971，Pp. 59 